\title{
EDITORIAL
}

\section{A YEAR OF IMPORTANT ANNIVERSARIES}

We have entered the sixteenth year of the publication Contemporary Military Challenges with a wish to mark a few important anniversaries. In 2004, Slovenia joined the European Union and became a NATO member. Slovenia has thus been an active member of two distinguished international organisations for ten years. At the same time, this denotes a decade of active participation of Slovenian Armed Forces members in international operations and missions organised by the Alliance. In addition, it is the year in which the Slovenian Armed Forces reached the full age of its presence in the international environment. Eighteen years ago, in May 1997, twenty five members of Slovenian Armed Forces medical unit were deployed to a peace operation ALBA in Albania.

If we look deeper into the past, Slovenian General Rudolf Maister was born one hundred and forty years ago. He significantly influenced the evolution of developments before World War I, but mostly Slovenian national consciousness.

This year marks the hundredth anniversary of the beginning of World War I. The anniversary itself or the reasons for it are certainly not motivational - quite the opposite. It was an event on a worldwide scale which caused a great number of deaths and thus represented a devastating catastrophe. At that time, people did not even imagine what wars could bring for the future generations.

All these anniversaries, and more could be found, impacted the substantive premise of this year's issues. This is, of course, not because we would wish to turn backwards and deal with the historical issues. After all, we are the "Contemporary Military Challenges". What mainly interests us is what have we learned from these examples and experiences. Is today's situation any different because of them? Are we any better? 
For this purpose, we have published on our Slovenian (http://www.slovenskavojska. si/publikacije/sodobni-vojaski-izzivi/) and English (http://www.slovenskavojska. si/publikacije/sodobni-vojaski-izzivi/) websites an invitation for authors who would wish to deal with this subject. We are an interdisciplinary scientific and technical publication, which publishes articles on topical issues, research and expert discussions, as well as on technical and social science analyses covering the fields of international and national security and defence; global security challenges; crisis management; civil-military cooperation, and operations, development and transformation of the armed forces. The main topics that entertain our interest have been incorporated into the titles of individual issues. This year's second issue will be entitled "Recent education and training trends in security, defence and military sectors", the third one "Ten years of Slovenia's NATO membership", and the fourth one " $100^{\text {th }}$ anniversary of the beginning of World War I - have we learned anything from the conflicts in the past 100 years".

This year's first issue was reserved for the topics suggested by the authors and we have received some very interesting articles.

Ljubo Štampar in his article entitled Respect for human rights and fundamental freedoms in armed forces of EU member states: approaches, practices and mechanisms presents, in relation to the armed forces, the human rights and freedoms as the foundations of modern democratic societies. He compares freedom of speech, right to announce candidacy in the election or join political parties, freedom of association, freedom of trade unions and right to strike in individual EU member states.

Vinko Vegič in his article The role of armed forces in Europe: from territorial defence to various security tasks establishes that two of the most important changes in the role of the armed forces include the need for a defence of the territory, and the appearance of some relatively differing and often poorly defined tasks. Countries have to adapt their defence doctrines and military structure to these two subjects, whereby the public (potentially) plays a decisive role.

The young, patriotism and national security: armed forces as a pillar of patriotic structures is the article by Vladimir Prebilič and Jelena Juvan. The authors base their findings on the circumstances already described by Vinko Vegič, and establish the relation among the system of national security, values and patriotism among young people in Slovenia. Do the results of the survey represent a cause for concern?

The transformation of armed forces has been a topical issue, especially in the recent two years, and has intrigued Mihael Nagelj enough to verify the theoretical and practical understanding of this notion in the defence system. His findings are presented in the article entitled Defence sector transformation: as understood in the world and Slovenia. 
Tomaž Pajntar, the author of the article Security of buildings in the event of a terrorist bomb attack writes about a blast as a result of an explosion and its effects on the buildings and their security. He carefully analyses and illustrates the laws of explosions, the knowledge of which is very important in the provision of building security.

In her article entitled Information management and network collaboration in the Slovenian Armed Forces - a necessity or only a topical issue, Dragica Dovč presents the theory and practice of terms that at first seem very familiar. However, the results of her survey based on the case of the Slovenian Armed Forces, reveal that this field of work is still fairly unexplored.

So, here is one more reason for other friends of defence and military topics to join the group of writers. 